\title{
Yeast Cell Cake Characterization in Alcohol Solution for Efficient Microfiltration
}

\author{
Nobuyuki Katagiri ${ }^{1, *(\mathbb{D}}$, Keisuke Tomimatsu ${ }^{2}$, Keiichi Date ${ }^{2}$ and Eiji Iritani ${ }^{2}$ \\ 1 Department of Environmental Technology, Meijo University, 1-501 Shiogamaguchi, Tempaku-ku, \\ Nagoya 468-8502, Japan \\ 2 Department of Chemical Engineering, Nagoya University, Furo-cho, Chikusa-ku, Nagoya 464-8603, Japan; \\ tifamgreenline@gmail.com (K.T.); keiichidate@gmail.com (K.D.); iritani@nuce.nagoya-u.ac.jp (E.I.) \\ * Correspondence: katagiri@meijo-u.ac.jp; Tel.: +81-52-838-2368
}

Citation: Katagiri, N.; Tomimatsu,

K.; Date, K.; Iritani, E. Yeast Cell Cake Characterization in Alcohol Solution for Efficient Microfiltration.

Membranes 2021, 11, 89.

https://doi.org/10.3390/

membranes 11020089

Academic Editor: Hidetaka Kawakita

Received: 21 December 2020

Accepted: 25 January 2021

Published: 27 January 2021

Publisher's Note: MDPI stays neutral with regard to jurisdictional claims in published maps and institutional affiliations.

Copyright: (C) 2021 by the authors. Licensee MDPI, Basel, Switzerland. This article is an open access article distributed under the terms and conditions of the Creative Commons Attribution (CC BY) license (https:// creativecommons.org/licenses/by/ $4.0 /)$.

\begin{abstract}
Microfiltration is widely used to remove microbial cells from the fermentation broth in the downstream processing of biotechnological products. Because filtration behaviors are strongly affected by the characteristics of the microbial cell cake formed on the surface of the membrane, insights into the cake structure facilitate the design and operation of filter equipment and membranes. In the alcohol fermentation process using a yeast strain, the cake characteristics are considered to be complicated because yeast cells are strongly influenced by external factors such as filtration pressure and alcohol concentration. In this study, we evaluated the membrane filtration properties, in particular the cake characteristics of a yeast suspension containing alcohol. Microfiltration experiments were performed in the dead-end filtration mode using yeast suspensions with several ethanol concentrations $(0-20 \mathrm{wt} \%)$ under constant pressure. Flux decline behaviors caused by yeast cake were put in a similar form for $0-15 \mathrm{wt} \%$ ethanol concentrations. In contrast, a severe flux decline was observed for the suspension with $20 \mathrm{wt} \%$ ethanol concentration. It was also observed that in the membrane filtration of yeast cells with $20 \mathrm{wt} \%$ ethanol concentration, the cake structure became denser and the filtration resistance remarkably increased because of cellular destruction. Furthermore, the yeast cake exhibited a high compressibility in the solution containing a $20 \mathrm{wt} \%$ ethanol concentration. Therefore, the filtration rate of the alcoholic fermentation broth is not significantly improved by increased pressure due to the increase in the cake resistance.
\end{abstract}

Keywords: microfiltration; yeast; alcohol fermentation; fouling; cake resistance; cake porosity

\section{Introduction}

Microfiltration for the separation of particles has become increasingly important in various fields, including chemical and bio-industries. Membrane fouling is recognized as the most significant problem in the microfiltration process as it produces a drastic increase in the filtration resistance as the filtration progresses. Membrane fouling is caused by several factors such as the deposition of particles on the membrane surface referred to as the filter cake, and membrane pore-clogging and constriction [1-5]. Therefore, the mechanism underlying membrane fouling should be analyzed to control the microfiltration behavior of particles.

In the downstream processing of biotechnological products, microfiltration is used to remove the microbial cells from the fermentation broth. Because the impact of cake formation is one of the most significant factors influencing membrane fouling, the filtration behavior of the fermentation broth is strongly affected by the characteristics of the filter cake formed by the accumulation of cells on the membrane surface [6-9]. Therefore, knowledge of the cake structure provides valuable information for the design and operation of the filter equipment and membrane. During the alcohol fermentation process, the cake characteristics are considered to be complicated because microbial cells are strongly influenced by external factors such as filtration pressure and alcohol concentration. Yeast is the 
best-known ethanol-producing microorganism that is responsible both for the production of alcoholic beverages as well as bioethanol that is produced for use as a renewable fuel. In bioethanol production by yeast fermentation, attempts have been made to increase the ethanol concentration while reducing the required energy $[10,11]$. On the other hand, it has been reported that the dead yeast cells are observed in the fermentation broth containing a $20 \mathrm{vol} \%$ ethanol concentration [12]. Therefore, it is important to examine the filtration behaviors and cake characteristics of yeast under higher alcohol concentrations. Moreover, it is also necessary to obtain the dependences of the cake characteristics such as the average specific resistance and average porosity on the filtration pressure since yeast cell cakes have high compressibility [7-9].

Microfiltration is realized at the cross-flow mode or the dead-end mode with periodical backwashing to prevent the membrane from being fouled with deposits [13-16]. Redkar and Davis [17] observed that the initial transient flux decline in the cross-flow filtration of yeast follows the dead-end filtration theory. Furthermore, numerous investigations show that the resistances of yeast cakes both in cross-flow and dead-end filtration are similar $[18,19]$. As the most severe membrane fouling occurs in the dead-end mode, it is desirable to examine dead-end microfiltration behaviors in detail to clarify the role of the filter cake. Recently, several dead-end mode filtration tests have been proposed to accurately and simply determine the cake characteristics [8,20-26]. Among the cake characteristics, both the average specific cake resistance and average cake porosity, being related to the filterability, are recognized as the most important factors controlling membrane filtration behaviors. Murase et al. [20] developed a technique for accurately determining the average cake porosity in constant-pressure filtration based on the principle of a sudden reduction in the filtration area of the cake surface during the course of filtration. Iritani et al. [26] suggested a novel method for determining the average specific resistance and average porosity of filter cake, overlying the membrane in dead-end filtration, from only the flux decline behavior observed in two membrane filtration tests without using any specially designed filtration cells. It is considered that these filtration tests are also advantageous to the evaluation of the average specific resistance and average porosity of microbial cakes [9].

From the various approaches applied for dead-end microfiltration of microbial suspensions, both cells and metabolites have been shown to have significant effects on membrane fouling [6-9,27-32]. However, the cake characteristics and the effect of alcohol on yeast cake during membrane filtration of the alcoholic fermentation broth is not completely understood. In this study, we evaluated the membrane filtration properties, particularly the cake characteristics, of a yeast suspension containing ethanol in the dead-end mode, and investigated the effects of pressure and ethanol concentration on the separation of yeast. The results of this study, particularly regarding the effect of cell deformability on the cake characteristics in alcohol solutions, provide a promising strategy for efficient microfiltration that could be utilized for the production of bioethanol.

\section{Materials and Methods}

\subsection{Materials}

Sake Yeast NBRC2347 was used in this study. The yeast cells were inoculated into $200 \mathrm{~mL}$ of a medium ( $1 \%$ glucose, $0.5 \%$ peptone, $0.3 \%$ yeast extract, $0.3 \%$ malt extract) contained in a $500 \mathrm{~mL}$ Erlenmeyer flask. The flask was shaken at $200 \mathrm{rpm}$ and $30{ }^{\circ} \mathrm{C}$ in a shaking incubator (BR-33FL, Taitec Corp., Saitama, Japan) to prepare the cell suspension culture. After cultivation, cell suspensions were centrifuged for $15 \mathrm{~min}$ at $3000 \mathrm{rpm}$, and the cells were washed twice by resuspending and centrifuging them in the Mcllvaine buffer (10 mM citric acid-20 $\mathrm{mM} \mathrm{Na}_{2} \mathrm{HPO}_{4}, \mathrm{pH} 7.0$ ) containing ethanol [33]. They were again suspended in the buffer and used for microfiltration experiments. The cell concentration $s_{\mathrm{C}}$ was determined by modifying the method of Ju and Ho [34] and expressed as the wet weight of cells per unit weight of the suspension. 


\subsection{Experimental Apparatus and Technique}

Microfiltration experiments were conducted in a dead-end filtration mode using yeast suspensions containing ethanol at various concentrations $(0,5,10,15$, and $20 \mathrm{wt} \%)$ under conditions of a constant pressure varying over the range from 1 to $500 \mathrm{kPa}$ by adjusting the applied filtration pressure. Two types of unstirred batch filtration cells were utilized. A regular filtration cell was used to obtain a thick filter cake. To evaluate the average porosity $\varepsilon_{\mathrm{av}}$ of the filter cake, a filtration cell was used that was specifically designed for this study. In the case of this filtration cell, the filtration area was suddenly reduced from 16.88 to $2.58 \mathrm{~cm}^{2}$ by constructing an orifice structure at a distance $h$ of $0.98 \mathrm{~mm}$ from the membrane surface, as shown in Figure 1. The filter medium used was a microfiltration membrane, made of a mixed cellulose ester, with a nominal pore size of $0.45 \mu \mathrm{m}$, supplied by Advantec Toyo Corp., Tokyo, Japan. The filtrate was collected in a reservoir placed on an electronic balance (Shimadzu Corp., Kyoto, Japan) connected to a personal computer to collect and record the mass versus time data. The weights were converted to volumes using density correlations, and the filtration rate $J_{\mathrm{v}}(=\mathrm{d} v / \mathrm{d} \theta)$ at various volumes was computed by numerical differentiation of volume $v$ versus time $\theta$ data. The filtrate was analyzed using a spectrophotometer (UV-1800, Shimadzu Corp.). The experiments were performed more than three times to ensure the reproducibility of the results. The cell cake was coated with gold using a sputter coater (MP-19020NCTR, JEOL Ltd., Tokyo, Japan), and an image of the bottom surface of the cake was obtained using a scanning electron microscope (JCM-5000, JEOL Ltd.).

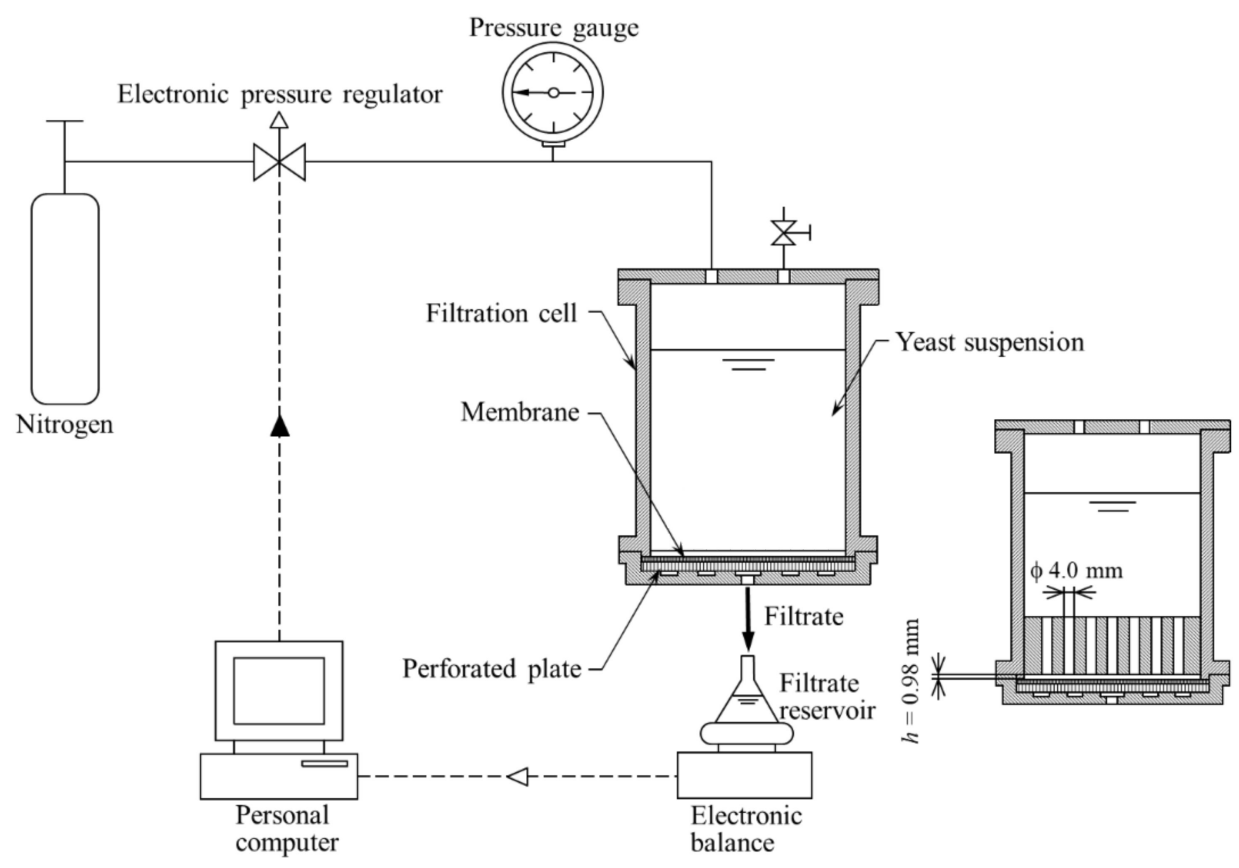

Figure 1. Schematic of the apparatus for microfiltration test.

\section{Results and Discussion}

\subsection{Membrane Filtration Properties}

The cake filtration rate $(\mathrm{d} v / \mathrm{d} \theta)$ under constant pressure can be generally represented by the Ruth filtration rate equation [35]:

$$
\frac{\mathrm{d} \theta}{\mathrm{d} v}=\frac{2}{K_{\mathrm{v}}}\left(v+v_{\mathrm{m}}\right)=\frac{\mu \rho s_{\mathrm{c}} \alpha_{\mathrm{av}}}{p\left(1-m s_{\mathrm{c}}\right)}\left(v+v_{\mathrm{m}}\right)
$$

where $\theta$ is the filtration time, $v$ is the cumulative filtrate volume per unit membrane area, $K_{\mathrm{v}}$ is the Ruth coefficient of constant pressure filtration, $v_{\mathrm{m}}$ is the fictitious filtrate volume per unit membrane area, equivalent to the flow resistance of membrane, $\mu$ is the viscosity of the 
filtrate, $\rho$ is the density of the filtrate, $s_{\mathrm{C}}$ is the mass fraction of wet cells in suspension, and $p$ is the applied filtration pressure. In Figure $2 \mathrm{a}$, the filtration behavior of the yeast suspension is plotted as the reciprocal filtration rate $(\mathrm{d} \theta / \mathrm{d} v)$ against the cumulative filtrate volume $v$ per unit membrane area. The plots are virtually linear in accordance with Equation (1) during filtration, and the $Y$-axis intercept near the origin indicates that the cake resistance is significantly higher than the membrane resistance. Consequently, the average specific cake resistance $\alpha_{\mathrm{av}}$ that is a measure of the filterability of the suspension, can be calculated as:

$$
\alpha_{\mathrm{av}}=\frac{2}{K_{\mathrm{v}}} \cdot \frac{p\left(1-m s_{\mathrm{c}}\right)}{\mu \rho s_{\mathrm{c}}}
$$

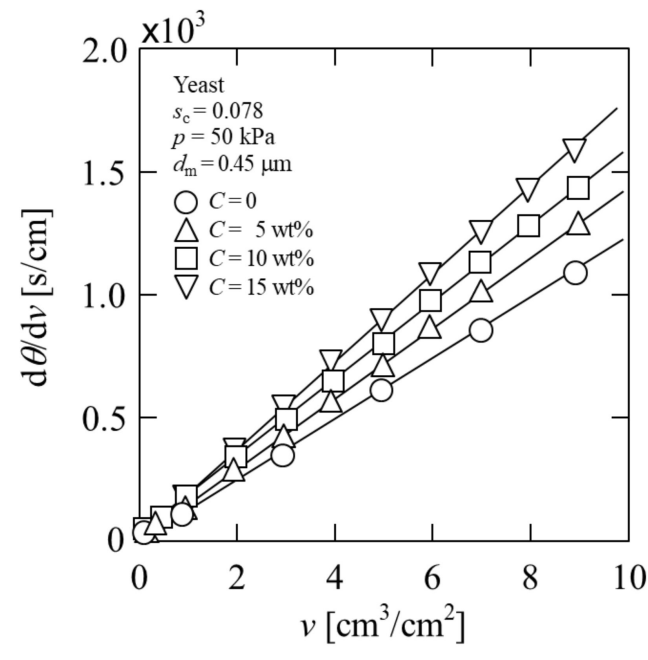

(a) $\mathrm{d} \theta / \mathrm{d} v$ versus $v$

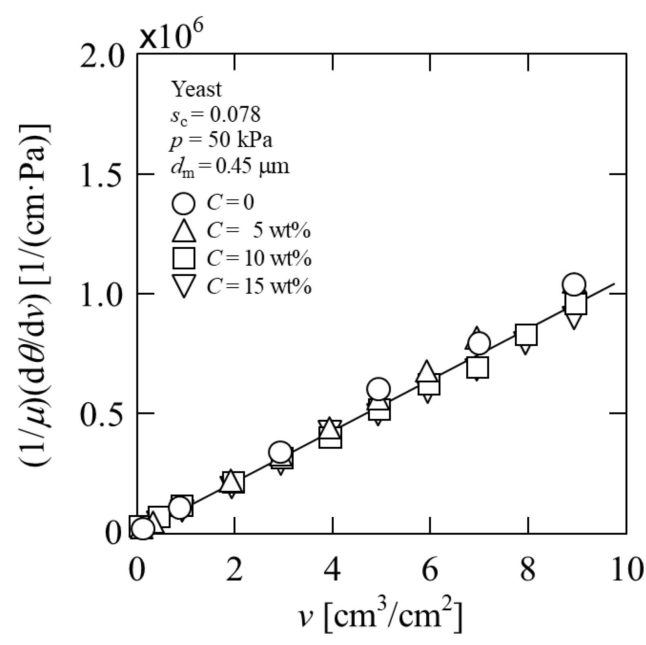

(b) $(1 / \mu) \cdot(\mathrm{d} \theta / \mathrm{d} v)$ versus $v$

Figure 2. Microfiltration behavior of yeast suspension $(C=0-15 \mathrm{wt} \%)$ : (a) $\mathrm{d} \theta / \mathrm{d} v$ versus $v$; (b) $(1 / \mu) \cdot(\mathrm{d} \theta / \mathrm{d} v)$ versus $v$.

The variable $m$ indicates the average ratio of the mass of wet cake to the mass of dry cake and is related to the average porosity $\varepsilon_{\mathrm{av}}$ of the filter cake as:

$$
m=1+\frac{\rho \varepsilon_{\mathrm{av}}}{\rho_{\mathcal{c}}\left(1-\varepsilon_{\mathrm{av}}\right)}
$$

where $\rho_{\mathrm{c}}$ is the true density of the wet cells. It is assumed that the internal water of the cells is not drained during the filtration period [36].

In Figure 2a, the slope of the plot increases with increasing ethanol concentration $C$ in the yeast suspension, indicating that the filtration resistance becomes higher from the existence of ethanol. As can be seen in Equation (1), the value of the slope is influenced by the viscosity of the filtrate, and it is well-known that the viscosity of the liquid changes when the ethanol content changes. Therefore, in Figure $2 b$, the constant pressure filtration data are replotted in the form of $(1 / \mu) \cdot(\mathrm{d} \theta / \mathrm{d} v)$ against the cumulative filtrate volume $v$ per unit membrane area, in accordance with Equation (4):

$$
\frac{1}{\mu} \cdot \frac{\mathrm{d} \theta}{\mathrm{d} v}=\frac{\rho s_{\mathrm{c}} \alpha_{\mathrm{av}}}{p\left(1-m s_{\mathrm{c}}\right)}\left(v+v_{\mathrm{m}}\right)
$$

Flux decline behaviors were put in a similar form for $0-15 \mathrm{wt} \%$ ethanol concentrations. This indicates that the cake resistance does not change with or without ethanol. The plot in Figure $2 b$ is useful for representing the filtration behavior in the case where the liquid viscosity is variable.

In contrast, a severe flux decline is observed for the suspension with $20 \mathrm{wt} \%$ ethanol concentration, as shown in Figure 3. In this case, the increase in the slope of the plot 
is attributed to the characteristics of the cake formed on the membrane surface, and indicates that the values of $\alpha_{\mathrm{av}}$ and $m$ have changed significantly, as can be inferred from Equation (4). This flux decline behavior is confirmed even at the ethanol concentration of $25 \mathrm{wt} \%$ (data not shown), and is considered to be a characteristic behavior when the alcohol concentration is high. It is known that the increased concentration of ethanol influences the cell membrane fluidity and is toxic to the membrane proteins, leading to cell growth inhibition, and even death [37]. That is, the effect of high-concentration alcohol on cells has evidently induced changes in the cake characteristics. Although there have been attempts to increase the ethanol concentration in bioethanol production $[10,11]$, the microfiltration test results indicate that the filterability is significantly reduced under high ethanol concentrations.

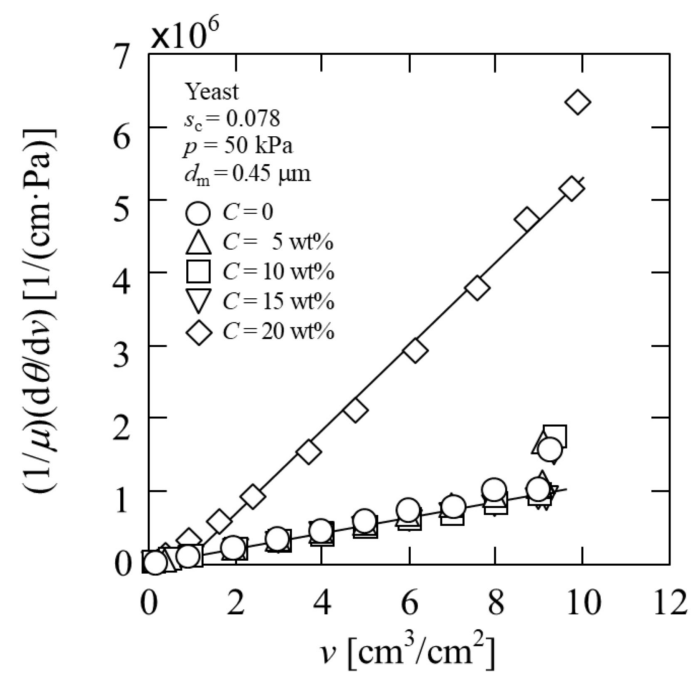

Figure 3. Microfiltration behavior of yeast suspension $(C=0-20 \mathrm{wt} \%)$.

\subsection{Characteristics of Yeast Cell Cake}

The average specific resistance $\alpha_{\mathrm{av}}$ and average porosity $\varepsilon_{\mathrm{av}}$ of the yeast cell cake were measured based on cake filtration theory. To evaluate the average porosity $\varepsilon_{\mathrm{av}}$ of the filter cake, a specifically designed filtration cell was used. Once the surface of the filter cake reaches the position where the inner cross-sectional area of the filter chamber is suddenly reduced from 16.88 to $2.58 \mathrm{~cm}^{2}$, the filtrate flow rate decreases dramatically because of the decrease in the surface area of the filter cake. Consequently, the plot of $\mathrm{d} \theta / \mathrm{d} v$ against $v$ calculated by filtration area $16.88 \mathrm{~cm}^{2}$ shows a significant deviation from the previous linear relationship, as shown in Figure 3. The thickness $L$ of the filter cake at the transition point is equal to the distance $h$ from the membrane surface to the orifice structure [20]. With respect to the overall mass balance in filtration, the distance $h$ is directly related to the filtrate volume $v_{\mathrm{t}}$ per unit membrane area at the transition point based on the following equation [9]:

$$
w_{\mathrm{t}}=\frac{\rho s_{\mathrm{c}}}{1-m s_{\mathrm{c}}} v_{\mathrm{t}}=\rho_{\mathrm{c}}\left(1-\varepsilon_{\mathrm{av}}\right) h
$$

where $w_{\mathrm{t}}$ is the mass of wet cells per unit membrane area at the transition point. Therefore, substituting Equation (3) into Equation (5) results in the following equation [9]:

$$
\varepsilon_{\mathrm{av}}=\frac{\rho_{\mathrm{c}}\left(1-s_{\mathrm{c}}\right) h-\rho s_{\mathrm{c}} v_{\mathrm{t}}}{\rho_{\mathrm{c}}\left(1-s_{\mathrm{c}}\right) h+\rho s_{\mathrm{c}} h}
$$

Figure 4 represents the relationship between the cake characteristics and ethanol concentration $C$. At an ethanol concentration of $15 \mathrm{wt} \%$, the value of the average specific cake resistance $\alpha_{\mathrm{av}}$ almost remained unchanged as the concentration increased, as shown in Figure $4 \mathrm{a}$. However, $\alpha_{\mathrm{av}}$ at $20 \mathrm{wt} \%$ was much higher than that at $0-15 \mathrm{wt} \%$, and the value was changed by one order of magnitude. In Figure $4 b$, the solidosity $\left(1-\varepsilon_{\mathrm{av}}\right)$ is plotted 
against the ethanol concentration. The result was similar to that of $\alpha_{\mathrm{av}}$, and the value of solidosity at $C=20 \mathrm{wt} \%$ was different from those at the other ethanol concentrations. In this study, we calculated the average cake porosity $\varepsilon_{\mathrm{av}}$ using Equation (6). The gap between cells was considered as the void through which water drains. Therefore, when the solidosity $\left(1-\varepsilon_{\mathrm{av}}\right)$ exceeded 1.0, the internal water of the yeast cell was drained. The value of $\varepsilon_{\mathrm{av}}$ at $0-15 \mathrm{wt} \%$ was $0.35-0.4$, which was in agreement with the results of other studies $[14,33]$. In contrast, $\varepsilon_{\mathrm{av}}$ at $20 \mathrm{wt} \%$ was extremely low, indicating a significant increase in the filtration resistance.

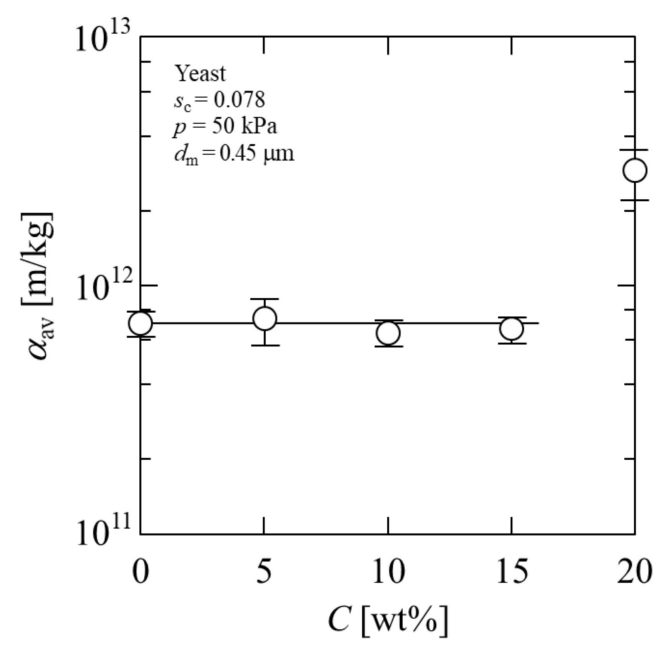

(a) $\alpha$ av versus $C$

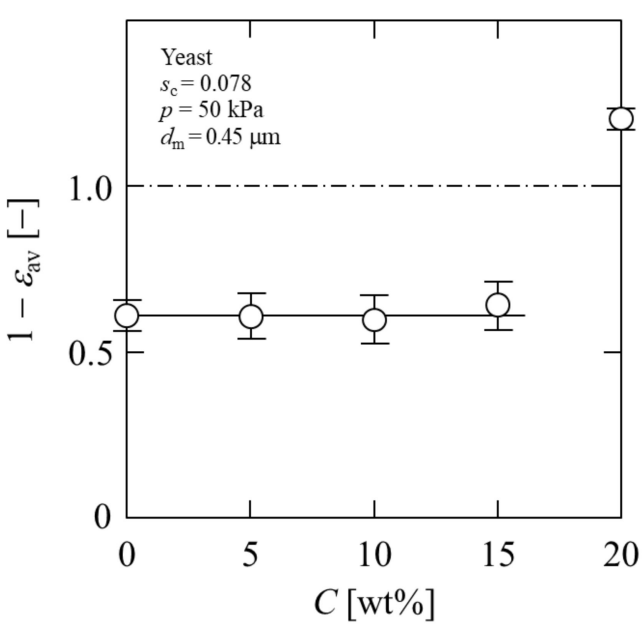

(b) $1-\varepsilon$ av versus $C$

Figure 4. Relationship between cake characteristics and ethanol concentration: (a) $\alpha_{\mathrm{av}}$ versus C; (b) $1-\varepsilon_{\mathrm{av}}$ versus $C$.

Figure 5 shows photographs of the yeast cake when the ethanol concentration $C$ is $0 \mathrm{wt} \%$ and $20 \mathrm{wt} \%$. The thickness of the yeast cake at $C=20 \mathrm{wt} \%$ (Figure $5 \mathrm{~b}$ ) was remarkably different from that at $C=0$ (Figure 5a), and the dehydration progressed and a hard cake was formed. The texture of the cake is clearly different, and it is speculated that the state of the yeast cells that comprise the cake has also changed. This result is consistent with what is inferred from the solidosity data in Figure $4 \mathrm{~b}$.

Figure 6 shows electron micrographs of the bottom surface of the cake. Looking at the yeast cells that comprise the cake, each cell can be confirmed at $C=0$, whereas the cells are bound to each other at $C=20 \mathrm{wt} \%$. It is known that ethanol is destroys the membrane structure of yeast cells [37], and Urbanczyk et al. [12] observed that the percentage of dead cells increased with an increasing ethanol concentration of the fermentation broth. It can be seen that the high concentration of ethanol has damaged the cell membrane and has affected the cake structure.

Furthermore, a clear difference was observed in the filtrate at $C=20 \mathrm{wt} \%$. As can be seen from the photograph shown in Figure 7, yellow coloring is observed in the filtrate at $C=20 \mathrm{wt} \%$, although it is not observed at $C=0$. It is possible that metabolites have been discharged from the yeast cells. The filtrate was analyzed with a spectrophotometer; the spectrum is shown in Figure 8 . At a filtration pressure of $1 \mathrm{kPa}$, there was no difference based on the ethanol concentration; however, at a filtration pressure of $10 \mathrm{kPa}$, a peak was observed near $260 \mathrm{~nm}$ at $C=20 \mathrm{wt} \%$. This suggests that the cells were destroyed, and intracellular metabolites such as nucleic acid were discharged into the filtrate under a pressure above $10 \mathrm{kPa}$ at $C=20 \mathrm{wt} \%$. This phenomenon has a great influence on the quality of alcoholic beverages. Furthermore, with respect to the dehydration of microbial cakes, it is considered that such findings may be applied to the establishment of an efficient dehydration method for microbial cells. From these results, it is confirmed that the cake 
structure becomes denser and the filtration resistance is remarkably increased during the filtration of yeast suspensions with high alcohol concentrations.

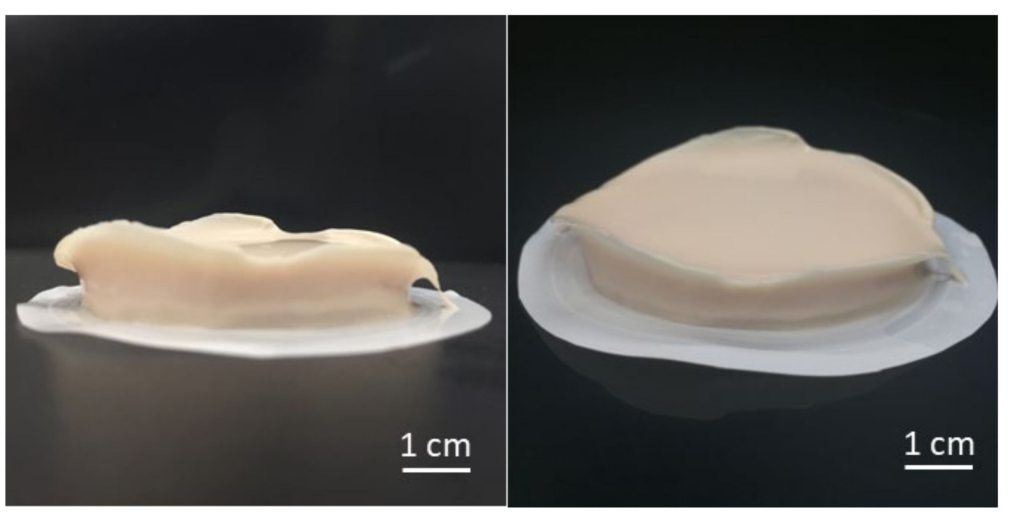

(a) $C=0$

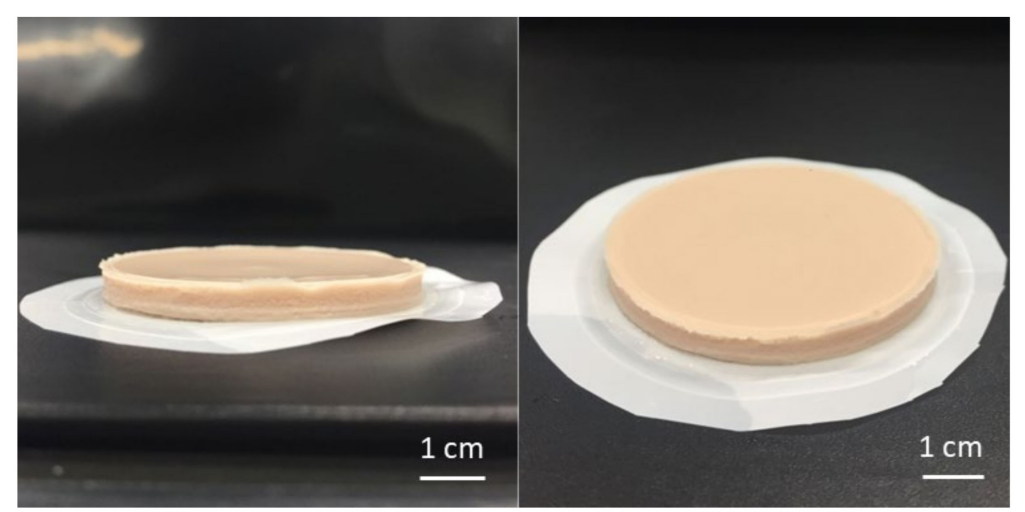

(b) $C=20 \mathrm{wt} \%$

Figure 5. Photo of filter cake $\left(s_{\mathrm{C}}=0.078, p=50 \mathrm{kPa}\right):(\mathbf{a}) C=0 ;(\mathbf{b}) C=20 \mathrm{wt} \%$.

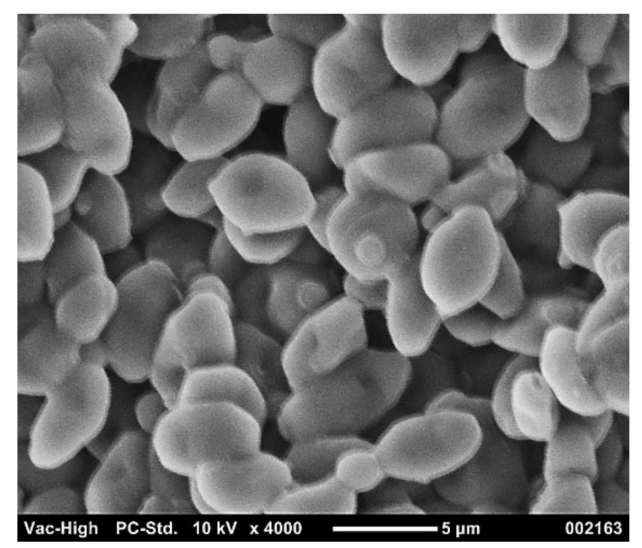

(a) $C=0$

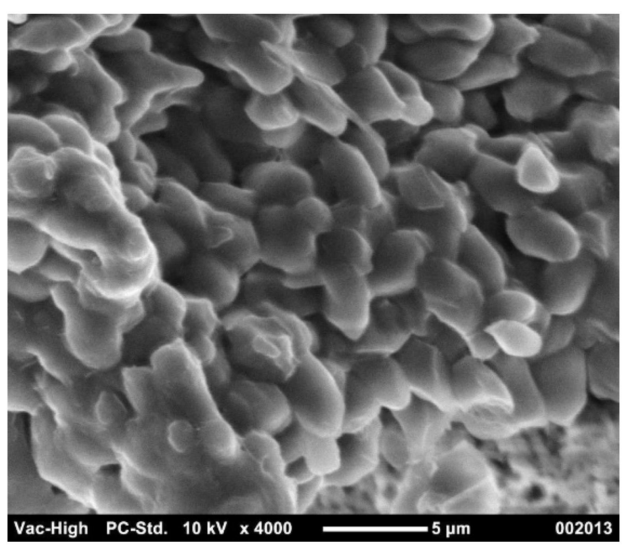

(b) $C=20 \mathrm{wt} \%$

Figure 6. Electron micrograph of filter cake $\left(s_{\mathrm{C}}=0.078, p=50 \mathrm{kPa}\right):(\mathbf{a}) C=0 ;(\mathbf{b}) C=20 \mathrm{wt} \%$. 


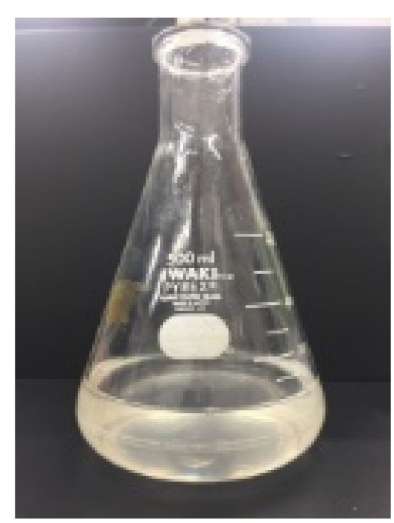

(a) $C=0$

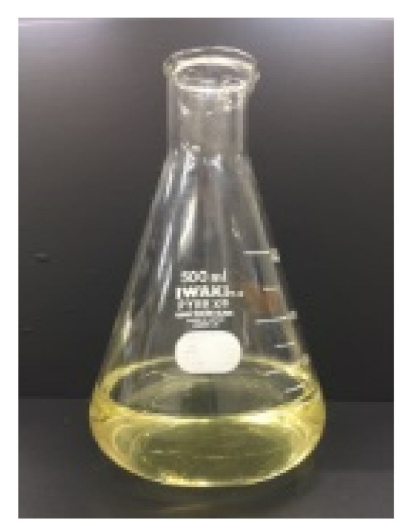

(b) $C=20 \mathrm{wt} \%$

Figure 7. Photo of filtrate $\left(s_{\mathrm{C}}=0.078, p=50 \mathrm{kPa}\right):(\mathbf{a}) C=0 ;(\mathbf{b}) C=20 \mathrm{wt} \%$.

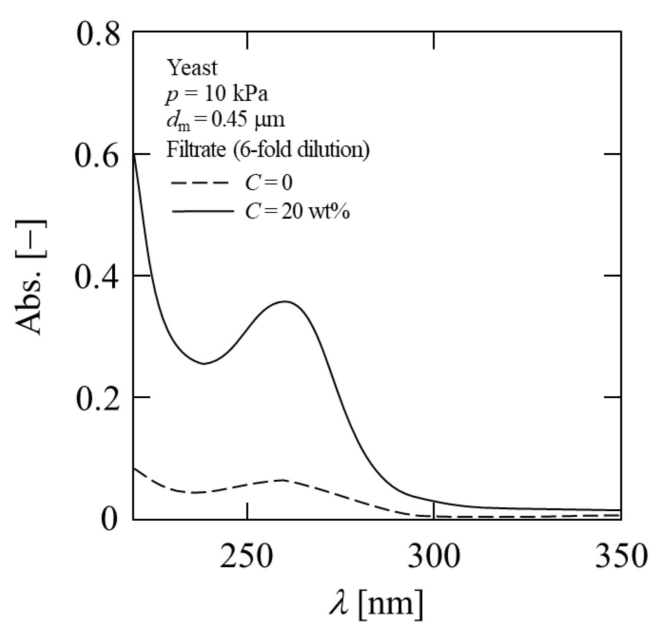

(a) $p=10 \mathrm{kPa}$

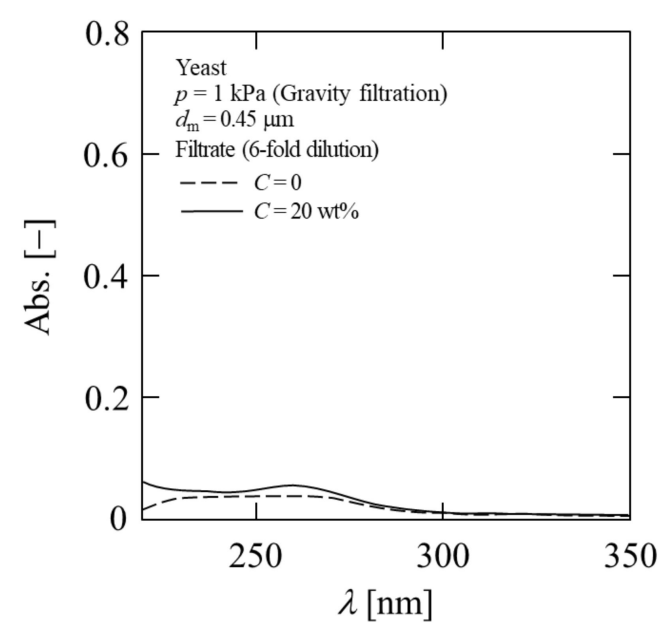

(b) $p=1 \mathrm{kPa}$

Figure 8. Spectrum of filtrate: (a) $p=10 \mathrm{kPa}$; (b) $p=1 \mathrm{kPa}$.

In Figure 9, the average specific filtration resistance $\alpha_{\mathrm{av}}$ of the yeast cake is logarithmically plotted against the pressure $p$. In general, it is possible to empirically represent $\alpha_{\mathrm{av}}$ by the power function of $p$ for compressible filter cakes as follows [38]:

$$
\alpha_{\mathrm{av}}=\alpha_{1} p^{n}
$$

where $\alpha_{1}$ and $n$ are the empirical constants, and $n$ is a measure of the compressibility of the filter cake. However, in the case of microbial cake, it is known that Equation (7) can be applied above a certain pressure [6,31], and such behavior is observed at $C=0$ and $10 \mathrm{wt} \%$. In contrast, at $\mathrm{C}=20 \mathrm{wt} \%$, a particular behavior is observed that allowed Equation (7) to be applied in the pressure range from 10 to $500 \mathrm{kPa}$. It was clarified that in the high-concentration alcohol solution, the yeast cake was compressed even under low pressure, as in the case of high pressure. The values of the compressibility coefficient $n$ were calculated to be 0.740 and 0.695 for the yeast cake at $C=20 \mathrm{wt} \%$ and $C=0$, respectively. It should be noted that the filter cake formed at $\mathrm{C}=20 \mathrm{wt} \%$ shows a higher compressibility than that formed at $\mathrm{C}=0$. That is, the yeast cell present in the high-concentration alcohol solution causes a high compressibility of the filter cake. As a result, the filtration rate of the alcoholic fermentation broth is not significantly improved by the increased pressure due to the increase in the cake resistance. These findings will be useful for determining an efficient filtration pressure. 


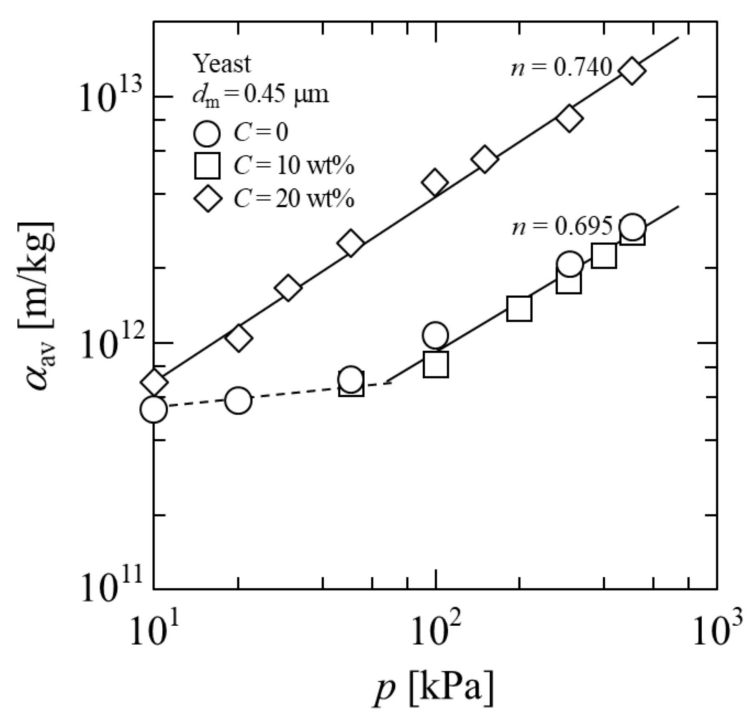

Figure 9. Logarithmic plot of average specific cake resistance against applied pressure.

\section{Conclusions}

The microfiltration properties of yeast suspensions containing ethanol at various concentrations were evaluated based on the compressible cake filtration theory. The cake structure became denser and the filtration resistance was increased remarkably for high ethanol concentrations of the suspension. The high-concentration ethanol influenced the yeast cell membrane, and the destroyed and deformed cells induced changes in the cake characteristics. The discharge of intracellular components into the filtrate has a great influence on the quality of alcoholic beverages. It was also clarified that in the highconcentration ethanol solution, the yeast cake was evidently compressed even under low pressure, and the filtration rate is not so much improved by the increase in the applied pressure. The results of the effect of cell deformability on cake characteristics in alcohol solution provide a promising strategy for an efficient microfiltration that could be employed for the production of bioethanol.

Author Contributions: Conceptualization, N.K. and E.I.; methodology, N.K.; formal analysis, K.T. and K.D.; investigation, K.T. and K.D.; writing —original draft preparation, N.K.; writing-review and editing, E.I. All authors have read and agreed to the published version of the manuscript.

Funding: This research was funded by JSPS KAKENHI, grant number JP 17K06889 and 20K05190.

Institutional Review Board Statement: Not applicable.

Informed Consent Statement: Not applicable.

Data Availability Statement: Not applicable.

Conflicts of Interest: The authors declare no conflict of interest.

\section{References}

1. Hwang, K.J.; Liao, C.Y.; Tung, K.L. Analysis of particle fouling during microfiltration by use of blocking models. J. Membr. Sci. 2007, 287, 287-293. [CrossRef]

2. Masoudnia, K.; Raisi, A.; Aroujalinan, A.; Fathizadeh, M. Treatment of oily wastewaters using the microfiltration process: Effect of operating parameters and membrane fouling study. Sep. Sci. Technol. 2013, 48, 1544-1555. [CrossRef]

3. Iritani, E. A review on modeling of pore-blocking behaviors of membranes during pressurized membrane filtration. Dry. Technol. 2013, 31, 146-162. [CrossRef]

4. Iritani, E.; Katagiri, N. Developments of blocking filtration model in membrane filtration. KONA Powder Part J. 2016, 33, 179-202. [CrossRef]

5. Iritani, E.; Katagiri, N.; Yamashita, Y. Effect of membrane morphology on rising properties of filtration resistance in microfiltration of dilute colloids. AIChE J. 2017, 63, 3511-3522. [CrossRef] 
6. Nakanishi, K.; Tadokoro, T.; Matsuno, R. On the specific resistance of cakes of microorganisms. Chem. Eng. Commun. 1987, 62, 187-201. [CrossRef]

7. Foley, G. A review of factors affecting filter cake properties in dead-end microfiltration of microbial suspensions. J. Membr. Sci. 2006, 274, 38-46. [CrossRef]

8. Iritani, E.; Nagaoka, H.; Katagiri, N. Determination of filtration characteristics of yeast suspension based upon multistage reduction in cake surface area under step-up pressure conditions. Sep. Purif. Technol. 2008, 63, 379-385. [CrossRef]

9. Katagiri, N.; Kawahara, H.; Arai, Y.; Iritani, E. Evaluation of compression-permeability characteristics of microbial cake based on microfiltration data. Sep. Sci. Technol. 2016, 51, 845-852. [CrossRef]

10. Alam, M.A.; Yuan, T.; Xiong, W.; Zhang, B.; Lv, Y.; Xu, J. Process optimization for the production of high-concentration ethanol with Scenedesmus raciborskii biomass. Bioresour. Technol. 2019, 294, 122219. [CrossRef]

11. Walker, G.M.; Walker, R.S.K. Enhancing yeast alcoholic fermentations. Adv. Appl. Microbiol. 2018, 105, 87-129. [CrossRef] [PubMed]

12. Urbanczyk, H.; Noguchi, C.; Wu, H.; Watanabe, D.; Akao, T.; Takagi, H.; Shimoi, H. Sake yeast strains have difficulty in entering a quiescent state after cell growth cessation. J. Biosci. Bioeng. 2011, 112, 44-48. [CrossRef] [PubMed]

13. Schluep, T.; Widmer, F. Initial transient effects during cross flow microfiltration of yeast suspensions. J. Membr. Sci. 1996, 115, 133-145. [CrossRef]

14. Tanaka, T.; Tsuneyoshi, S.; Kitazawa, W.; Nakanishi, K. Characteristics in crossflow filtration using different yeast suspensions. Sep. Sci. Technol. 1997, 32, 1885-1898. [CrossRef]

15. Hassan, I.B.; Ennouri, M.; Lafforgue, C.; Schmitz, P.; Ayadi, A. Experimental Study of membrane fouling during crossflow microfiltration of yeast and bacteria suspensions: Towards an analysis at the microscopic level. Membranes 2013, 3, 44-68. [CrossRef] [PubMed]

16. Akhondi, E.; Wicaksana, F.; Fane, A.G. Evaluation of fouling deposition, fouling reversibility and energy consumption of submerged hollow fiber membrane systems with periodic backwash. J. Membr. Sci. 2014, 452, 319-331. [CrossRef]

17. Redkar, S.G.; Davis, R.H. Crossflow microfiltration of yeast suspensions in tubular filers. Biotechnol. Prog. 1993, 9, 625-634. [CrossRef] [PubMed]

18. Tanaka, T.; Abe, K.; Asakawa, H.; Yoshida, H.; Nakanishi, K. Filtration characteristics and structure of cake in crossflow filtration of bacterial suspension. J. Ferment. Bioeng. 1994, 78, 455-461. [CrossRef]

19. Geissler, S.; Werner, U. Dynamic model of crossflow microfiltration in flat-channel systems under laminar flow conditions. Filtr. Sep. 1995, 32, 533-537. [CrossRef]

20. Murase, T.; Iritani, E.; Cho, J.H.; Nakanomori, S.; Shirato, M. Determination of filtration characteristics due to sudden reduction in filtration area of filter cake surface. J. Chem. Eng. Jpn. 1987, 20, 246-251. [CrossRef]

21. Iritani, E.; Katagiri, N.; Takaishi, Y.; Kanetake, S. Determination of pressure dependence of permeability characteristics from single constant pressure filtration test. J. Chem. Eng. Jpn. 2011, 44, 14-23. [CrossRef]

22. Iritani, E.; Katagiri, N.; Kanetake, S. Determination of cake filtration characteristics of dilute suspension of bentonite from various filtration tests. Sep. Purif. Technol. 2012, 92, 143-151. [CrossRef]

23. Iritani, E.; Katagiri, N.; Tsukamoto, M.; Hwang, K.J. Determination of cake properties in ultrafiltration of nano-colloids based on single step-up pressure filtration test. AIChE J. 2014, 60, 289-299. [CrossRef]

24. Iritani, E.; Katagiri, N.; Nakajima, R.; Hwang, K.J.; Cheng, T.W. Cake properties of nanocolloid evaluated by variable pressure filtration associated with reduction in cake surface area. AIChE J. 2014, 60, 3869-3877. [CrossRef]

25. Iritani, E.; Katagiri, N.; Nakajima, R.; Hwang, K.J.; Cheng, T.W. Nanocolloid cake properties determined from step-up pressure filtration with single-stage reduction in filtration area. AIChE J. 2015, 61, 4426-4436. [CrossRef]

26. Iritani, E.; Katagiri, N.; Masuda, H. Simplified Estimate of Cake Porosity in Dead-End Ultrafiltration of Protein Solution. J. Chem. Eng. Jpn. 2018, 51, 589-595. [CrossRef]

27. Iritani, E.; Katagiri, N.; Sengoku, T.; Yoo, K.M.; Kawasaki, K.; Matsuda, A. Flux decline behaviors in dead-end microfiltration of activated sludge and its supernatant. J. Membr. Sci. 2007, 300, 36-44. [CrossRef]

28. Hwang, K.J.; Tsai, P.C.; Iritani, E.; Katagiri, N. Effect of polysaccharide concentration on the membrane filtration of microbial cells. J. Appl. Sci. Eng. 2012, 15, 323-332.

29. Katagiri, N.; Chujo, K.; Takeuchi, A.; Iritani, E.; Kawasaki, K. Effect of BOD loading on solid-liquid separation properties of activated sludge. Kagaku Kogaku Ronbunshu 2009, 35, 99-104. [CrossRef]

30. Katagiri, N.; Yamauchi, K.; Kawasaki, K.; Iritani, E. Changes in membrane filtration properties of activated sludge and production of organic acid under anaerobic conditions. Kagaku Kogaku Ronbunshu 2017, 43, 289-295. [CrossRef]

31. Katagiri, N. Microfiltration of microbial suspension. Membrane 2020, 45, 22-28. [CrossRef]

32. Tomczak, W.; Gryta, M. Comparison of polypropylene and ceramic microfiltration membranes applied for separation of 1,3-PD fermentation broths and Saccharomyces cerevisiae yeast suspensions. Membranes 2021, 11, 44. [CrossRef] [PubMed]

33. McCarthy, A.A.; O'Shea, D.G.; Murray, N.T.; Walsh, P.K.; Foley, G. The effect of cell morphology on the filtration characteristics of the dimorphic yeast Kluyveromyces marxianus var. marxianus NRRLy 2415. Biotechnol. Prog. 1998, 14, 279-285. [CrossRef] [PubMed]

34. Ju, L.K.; Ho, C.S. Correlation of cell volume fractions with cell concentrations in fermentation media. Biotechnol. Bioeng. 1988, 32, 95-99. [CrossRef] [PubMed] 
35. Ruth, B.F. Studies in filtration. III. Derivation of general filtration equations. Ind. Eng. Chem. 1935, 27, 708-723. [CrossRef]

36. Sambuichi, M.; Otsuki, K.; Fujio, Y.; Ueda, S. Filtration and expression characteristics of baker's yeast. (I) Results of compression permeability test and constant pressure filtration. J. Ferment. Technol. 1971, 49, 880-885.

37. Ding, J.; Huang, X.; Zhang, L.; Zhao, N.; Yang, D.; Zhang, K. Tolerance and stress response to ethanol in the yeast Saccharomyces cerevisiae. Appl. Microbiol. Biotechnol. 2009, 85, 253-263. [CrossRef]

38. Sperry, D.R. Note and correspondence: A study of the fundamental laws of filtration using plant-scale equipment. Ind. Eng. Chem. 1921, 13, 1163-1164. [CrossRef] 